\title{
Whole-some artifacts: (STEM) Teaching and Learning Emerging from and Contributing to Community
}

Dawn Wiseman

Bishop's University, 2600 College St., Sherbrooke, QC, J1M 1 Z7

dwiseman@ubishops.ca

819-822-9600

ORCID: 0000-0001-6153-3183

Lisa Lunney Borden

St. Francis Xavier University

Faculty of Education, 4545 Alumni Drive, Antigonish, NS, B2G 2W5

lborden@stfx.ca

902-867-5132

Ruth Beatty

Lakehead University

Faculty of Education 500 University Ave., Orillia, ON, L3V 0B9

rbeatty@lakeheadu.ca

705-330-4008 ext. 2619

Limin Jao

McGill University

Faculty of Education, 3700 McTavish Street, Montreal, QC, H3A 1Y2

limin.jao@mcgill.ca

514-398-4527 ext. 089696

Ellen Carter

St. Francis Xavier University

Faculty of Education, 4545 Alumni Drive, Antigonish, NS, B2G 2W5

ecarter@stfx.ca

902-867-4916

Abstract: This paper braids together experiences from three Canadian projects committed to creating learning opportunities where Indigenous and Western ways of knowing, being, and doing might circulate together. Show Me Your Math/Connecting Math to Our Lives and Communities (Mi'kmaw territory/Nova Scotia), the First Nations and Métis Mathematics Voices Project (Anishnaabe territory/Ontario), and the READress Project (Kanien'kehá:ka

Wiseman, D., Lunney Borden, L., Beatty, R., Jao, L., \& Carter, E. (2020). Whole-some artifacts: (STEM) Teaching and learning emerging from and contributing to community. Canadian Journal of Science, Mathematics, and Technology Education, 20(2), 264-280. https://doi.org/10.1007/s42330-020-00079-6 
territory/Québec), are each described, and individually and collaboratively explored to identify the ways in which STEM, and mathematics, emerged (or did not) from community, and contributed back to those communities. While unique in their own ways, each of the projects engaged in collaborative, reflective, cyclical processes of teaching and learning that were deeply rooted in community and ethical relationality. Unresolved tensions are reviewed regarding what is lost when mathematics and STEM more generally are privileged in these contexts, and questions about curriculum reform are presented.

Keywords: STEM, community, Indigenous, mathematics

\section{Acknowledgements:}

The authors would like to thank Michael Marker (University of British Columbia) and the editors of this special issue for feedback on an earlier version of this paper. We also thank the following organizations for their support of the work presented in this paper:

- Social Sciences and Humanities Research Council of Canada (SSHRC) Insight Development Grant

- Council of Ontario Directors of Education

- Natural Sciences \& Engineering Research Council (NSERC) PromoScience

- Jeannine Deveau Educational Endowment Foundation

We have been invited by the editors of this special issue to consider our work in the context of science, technology, engineering, and mathematics (STEM), with particular attention to the $\mathrm{M}$ in STEM. There is some irony in this invitation, as we rarely refer to the work we do as STEM; the term often does not fit the contexts and communities in which we find ourselves. Nevertheless, we recognize that others may view the work as STEM in relation to how it aligns with integrated approaches to teaching and learning (Bybee, 2010a,b; Zollman, 2011, 2012) in which problems and questions are central and learners take up various elements of STEM as required in particular instances (Lunney Borden \& Wiseman 2016). We note also that this special issue is based on moving beyond conceptions of STEM that privilege neoliberal imperatives of growth, innovation, and economics (e.g. Government of Canada 2018a,b). We

Wiseman, D., Lunney Borden, L., Beatty, R., Jao, L., \& Carter, E. (2020). Whole-some artifacts: (STEM) Teaching and learning emerging from and contributing to community. Canadian Journal of Science, Mathematics, and Technology Education, 20(2), 264-280. https://doi.org/10.1007/s42330-020-00079-6 
have challenged such imperatives in previous work (Authors $1 \& 2$ ) to posit STEM (if that is the term to be used) as a living, whole-some artifact of teaching and learning instead of disciplining structures imposed on teaching and learning. This idea emerged from sites where students and teachers were engaged in interesting problems and questions connected to place and community, and mathematics arose organically in context alongside other disciplinary considerations. While the communities and places involved were different from each other, they shared a commitment to creating learning opportunities where Indigenous and Western ${ }^{1}$ ways of knowing, being, and doing might circulate together.

As non-Indigenous women working in relationship with Indigenous people, peoples, and communities, we know the best we can hope for is that Indigenous and non-Indigenous ways might circulate together, because we are constrained by the limits of the worldviews in which we were raised and have been educated. The five of us are at different stages of this work; some of us have engaged in "unlearning colonialism" (Donald 2018) with community for over a quarter century, others have entered the process in the last few years. Our commitments are both personal and-more recently-mandated. Personally, the commitments come from collaborations with First Nations, Métis, and Inuit people, peoples, and communities focused on attending to their aspirations for STEM education. Professionally, recent national and provincial mandates requiring the integration of Indigenous perspectives, contributions, and histories across K-12 and post-secondary teaching and learning impact us as teacher educators and researchers in post-

\footnotetext{
${ }^{1}$ We use the word "Western" here as the contexts for K-12 learning in what is currently Canada are largely framed in Western, and specifically, Euro-Canadian ways of knowing, being, and doing. In other places, we will use the term "non-Indigenous" to open up possibilities beyond the Western.

Wiseman, D., Lunney Borden, L., Beatty, R., Jao, L., \& Carter, E. (2020). Whole-some artifacts: (STEM) Teaching and learning emerging from and contributing to community. Canadian Journal of Science, Mathematics, and Technology Education, 20(2), 264-280. https://doi.org/10.1007/s42330-020-00079-6
} 
secondary institutions (e.g. Alberta Education 2018; Association of Canadian Deans of Education 2010; Ontario Ministry of Education 2007; Truth and Reconciliation Commission of Canada (TRC) 2015; Universities Canada 2015). While the mandates do not necessarily specify the importance of community or context, we find that it is only by engaging in community as context that we render the mandates meaningful and active in the world. This paper thus presents work from three different projects, in three different communities-Show Me Your Math (SMYM, Mi'kmaw territory/Nova Scotia), the First Nations and Métis Mathematics Voices Project (Anishnaabe territory/Ontario) and, the READress Project (Kanien’kehá:ka territory/Québec). It braids together stories of STEM and community to consider how STEM might both emerge from and contribute back to community. We begin by laying out the manner by which we enter into the work. Then, we explore conceptions of community, and how community is alive within our work. We move on to outline each of the three projects. Finally, we examine what the different projects suggest and the questions they raise-with some discussion of the mathematics in STEM-before considering how we might return to community to start again (Wiseman 2016).

\section{Entering into the work}

While we understand the importance of theory and methodology in framing research, we recognize that in research where different traditions might circulate together, such framings can shut down-rather than open up-possibilities (Meyer 2013). Thus, we attempt work that does not necessarily begin with or privilege research. Instead, we begin in relationship and see what comes from it, recognizing that sometimes research is not what is required (Tuck \& Yang 2014). Here we are guided by the people, peoples, and communities with whom we work, and a

Wiseman, D., Lunney Borden, L., Beatty, R., Jao, L., \& Carter, E. (2020). Whole-some artifacts: (STEM) Teaching and learning emerging from and contributing to community. Canadian Journal of Science, Mathematics, and Technology Education, 20(2), 264-280. https://doi.org/10.1007/s42330-020-00079-6 
family/iarity (Wiseman 2016) that allows for discussions of what is required in terms of respect, relevance, reciprocity, and responsibility (Kirkness \& Barnhardt 1991) in specific places, what Donald (2009) might call ethical relationality.

Ethical relationality works against the binaries of "colonial logics" (Donald 2009 p. 7) that divide people and peoples from their relations instead of opening a space where they coexist (Donald 2012). The framing allows us to attend to ongoing tensions in the work-between ways of knowing, being, and doing, between participants and researchers, between students and teachers-while still creating spaces where people might move closer together through iterative processes of collective learning (Donald 2009). The work is embedded in consensual collaborations where whole communities decide what is important. While there are various kinds of expertise within such relationality-e.g. research, teaching, STEM content knowledge etc.each is important to the result and no one person or group is privileged over the others, so all insights are important to what emerges (Donald, Glanfield, \& Sterenberg 2012). Ethical relationality is active within each of the projects described in this paper. It is also active in the paper itself through the use of métissage as a framing structure.

Chambers, Hasebe-Ludt, Donald, Hurren, Leggo and Oberg (2008) name métissage as a political, reading, writing and research praxis; an active, enacted, living practice of engaging with re/claiming, re/telling, and letting things be in relationship, difference, and multiple complexities. As a means of actively engaging in work, it asks researchers to consider the processes, places, and relationships of specific inquiries in multiple forms, "braiding" the results together through negotiation between author(s) and text(s) as a way of "resisting 19th-century scholarly conventions of discrete disciplines with corresponding rhetorics for conducting and

Wiseman, D., Lunney Borden, L., Beatty, R., Jao, L., \& Carter, E. (2020). Whole-some artifacts: (STEM) Teaching and learning emerging from and contributing to community. Canadian Journal of Science, Mathematics, and Technology Education, 20(2), 264-280. https://doi.org/10.1007/s42330-020-00079-6 
representing research" (p. 142), and thus we feel appropriate to considerations of what STEM might be. The braiding and negotiation serve as a means of creative activity where the resulting final product is both a part of and a result of the research. Within this paper, métissage provides a means through which the projects can be viewed as individual strands of a braid, that-when woven together-create a more whole-some image of how STEM emerges from and contributes to community.

\section{Conceptions of community}

Defining community is academically challenging (Cnaan, Milofsky, \& Hunter 2008; Franz, Skinner, \& Murphy 2018; Young, Spigner, Farwell, \& Stubblefield 2006). Franz et al. (2018) note that Hilary (1955) provided 94 definitions of community, "most of which, he concludes, are vague and not helpful" (p. 238). In general, there is the sense that community involves the coming together of people (the concept is largely anthropocentric), in particular places (physical or virtual), around some kind of sharing (of culture, of ideas, of practice, etc.). Importantly, there is an understanding that communities are complex and fluid with permeable boundaries, and that what constitutes particular communities often becomes more clear "as we talk about it" (Cnaan et al. 2008 p. 5). That is, research recognizes people understand what a community is in the daily-ness of living in it.

In education, the concept of community shares many of the features outlined above. Educational communities are recognized as complex entities where historical, cultural, political etc. contexts interact (Zeichner, Payne, \& Brayko 2014). They can be classrooms (e.g. Bielaczyc, Kapur, \& Collins 2013; Sergiovanni 1994) or whole schools (e.g. Bryk \& Driscoll 1988; Furman 2012), they can be limited to teaching staff or other populations within a school (e.g. Grossman,

Wiseman, D., Lunney Borden, L., Beatty, R., Jao, L., \& Carter, E. (2020). Whole-some artifacts: (STEM) Teaching and learning emerging from and contributing to community. Canadian Journal of Science, Mathematics, and Technology Education, 20(2), 264-280. https://doi.org/10.1007/s42330-020-00079-6 
Wineburg, \& Woolworth 2001; Hadar \& Brody 2010), they can also extend beyond a school to the physical and political community in which it is located (e.g. Warren 2005).

Ethical relationality (Donald 2009, 2012) works to extend our conceptions of community and how they are constituted. In its focus on consensual collaborations and the importance of all community members, ethical relationality may flatten the hierarchical structures often found in schools-theoretically, into a more interconnected, interrelated network, or-in terms of practiceinto places where teachers and students might live together in teaching and learning (Wiseman 2016). In addition, ethical relationality does not assume that the only location for understanding is human; it allows for communities that include other-than-human relatives as well as the land, air, and water, and that are emergent from complex conceptions of kinship and deep mutually sustaining relationships (Cajete 1994; Todd 2019). While such notions did not necessarily occur in all the projects informing this paper, they were potential, and are important considerations we attend to when considering community in our work.

\section{The projects and their communities}

While each of the projects that inform this paper engaged with communities focusing on STEM, and in some ways with mathematics, they were quite different in terms of location, participants, timeline, and outcomes. To provide context for the discussion that follows, key features of each project are presented below.

Show Me Your Math (Author 2 \& Author 5)

SMYM emerged from conversations with Elders about ethnomathematics, and subsequent meetings with Mi'kmaw teachers and other community members to discuss how children might engage in similar conversations (Lunney Borden, Wagner \& Johnson 2019;

Wiseman, D., Lunney Borden, L., Beatty, R., Jao, L., \& Carter, E. (2020). Whole-some artifacts: (STEM) Teaching and learning emerging from and contributing to community. Canadian Journal of Science, Mathematics, and Technology Education, 20(2), 264-280. https://doi.org/10.1007/s42330-020-00079-6 
Wagner \& Lunney Borden 2011, 2012). It eventually led to another program, Connecting Math to Our Lives and Communities (CMTOLC), that like SMYM, is built on community relationships and partnerships with four Mi'kmaw and three African Nova Scotian communities. Throughout the academic year, a project coordinator develops modules related to community knowledge and issues and supports a team of St. Francis Xavier University (StFX) students to deliver these hands-on investigations of mathematics. Goals include having K-12 students recognize the role mathematics plays in reading and writing the world (Gutstein, 2006), and identifying themselves as mathematicians in a way that honours their ways of being.

Often CMTOLC ideas are drawn from current events or on-going issues happening in the communities. For example, in one community, a fall storm caused a flood that washed away soil on a sacred island and uncovered graves. Technicians were brought into the community to use ground penetrating radar to find remaining graves and ensure safe burial away from the eroding sea line. We developed a module using a motion detector to explain how ground penetrating radar works.

First Nations and Métis Mathematics Voices Project (Author 3)

First Nations and Métis Mathematics Voices is a multi-year, multi-site study, where research teams across Ontario have collaboratively explored connections between mathematics inherent in Indigenous cultural practices and mathematical content in the Ontario curriculum. The research teams comprise Indigenous leaders, artists, and educators and non-Indigenous educators who, after consultation with community Elders and knowledge keepers, co-plan and co-teach units of mathematics instruction based on Indigenous activities and artifacts, and then together analyze and disseminate results. Although all teams explore culturally sustaining

Wiseman, D., Lunney Borden, L., Beatty, R., Jao, L., \& Carter, E. (2020). Whole-some artifacts: (STEM) Teaching and learning emerging from and contributing to community. Canadian Journal of Science, Mathematics, and Technology Education, 20(2), 264-280. https://doi.org/10.1007/s42330-020-00079-6 
mathematics education (Garcia \& Ingram Willis 2016), each individual project is local and driven by the views, opinions, resources, and interests of participating communities. The communities are sometimes specific First Nations, and other times-particularly in urban settings- emergent "intimate, human, and self-defined spaces" (Smith 1999 p.127). Our work utilizes a cyclical approach from consultation to dissemination to ensure that we continually cycle back to members of the community for guidance and feedback. The result is a holistic approach to mathematics instruction that incorporates cultural teachings, connections to Anishinaabemowin, and the basis for developing "intercultural understanding, empathy, and mutual respect" (TRC 2015 p. 7) by creating an opportunity for all students to experience Indigenous knowledge valued at the same level as Western knowledge. This approach also ensures that community members take the lead in directing the research. In phase one, we meet with community leaders who provide guidance, consider the proposal, and ultimately grant permission. The second phase is to learn an activity and conduct a preliminary investigation of its mathematical potential under the guidance of a local Indigenous artist. The third phase is for community partners to co-plan and co-teach sequences of lessons with the classroom teacher and other members of the research team. The fourth phase of the research cycle occurs during and after teaching, when as a team we co-reflect by analyzing the experiences to identify cultural connections and mathematical thinking. The final phase in the cycle is disseminating knowledge about what happens when community members, teachers, students, and researchers explicitly identify mathematics in a variety of First Nations and Métis activities.

The READress Project (Author 1 \& Author 4)

Wiseman, D., Lunney Borden, L., Beatty, R., Jao, L., \& Carter, E. (2020). Whole-some artifacts: (STEM) Teaching and learning emerging from and contributing to community. Canadian Journal of Science, Mathematics, and Technology Education, 20(2), 264-280. https://doi.org/10.1007/s42330-020-00079-6 
The READress Project was a collaborative exploration of student-directed STEAM (the added A “arts”) inquiry at a private girls' high school (Grades 7-11) in Montréal (Tiótia'ke). While located in Kanien'kehá:ka (Mohawk) territory, it did not begin with Indigenous contexts or by engaging with Indigenous ways of knowing, being, and doing. Instead, the project grew from the desire of the science and technology teacher, Raina ${ }^{2}$, to explore the potential of studentdirected STEAM. The project community consisted of the teacher, the two researchers, and 15 students in the Grade 7 cohort. From September to June, we met every two weeks for a 2-hour course period. Our initial focus was creating community, developing shared language around STEAM, and collectively choosing a project. Based on their own interests, students ultimately decided to work together to raise awareness about missing and murdered Indigenous women and girls (MMIWG). The choice of topic led to conversations about what we all really understood about MMIWG. Students researched how the topic was being taken up by Indigenous and Canadian journalists, governments, and artists. They were particularly taken with Métis artist Jaime Black's (2014) REDress Project, and decided to engage in a variation of it by designing and creating paper dresses. We named the project READress for two reasons. First, to indicate its connection to Black's work. Second to provide a sense of how the project allowed our community to "see and read through" (Ihde 1996 para. 29) STEAM to deeper understandings of MMIWG, relationships between Indigenous and non-Indigenous people, peoples, and communities in Canada, and the ongoing work of colonialism. The project culminated with a student-led vernissage of the dresses (Figure 1).

\footnotetext{
${ }^{2}$ Within the READress Project all names are pseudonyms. In the other projects real names are used with participant permission.

Wiseman, D., Lunney Borden, L., Beatty, R., Jao, L., \& Carter, E. (2020). Whole-some artifacts: (STEM) Teaching and learning emerging from and contributing to community. Canadian Journal of Science, Mathematics, and Technology Education, 20(2), 264-280. https://doi.org/10.1007/s42330-020-00079-6
} 
Fig. 1 Student dresses hanging for the project vernissage.

Throughout the project, mathematics-and the other elements of STEAM-were emergent because we were responding to students' decisions regarding project direction. Early in the process there were too many possibilities for understanding how mathematics might ariseexplorations of statistics, mapping of locations where women are known to go missing, etc. And in fact, in their research, students stumbled on to and were mobilized by some of these ways of exploring and characterizing the issue mathematically. However, it was only when they decided on designing paper dresses that it became evident that the majority of the mathematics in the project would reside in measuring, designing, and explaining (Bishop 1988).

\section{STEM emerging from communities}

We recognize that in education "emergence" is often connected to complexity thinking (Davis, Sumara, \& Luce-Kapler 2015) and post-modern conceptions of curriculum associated with Deleuzian thought (Aoki 2005; Wallin 2011). These ideas are useful for thinking with as they shift curriculum from a negotiable thing to a means of becoming. At the same time, in the contexts of our work, we struggle with such framings because they are grounded in Western thought, and we are attempting to find ways in which Indigenous and Western (and perhaps other) ways of knowing, being, and doing might circulate together. Thus emergence in our work begins from the position of taking Indigenous ways of knowing, being, and doing seriously (Stewart-Harawira 2005)-everything else follows. This positioning is a pedagogical choice that, like mathematics in STEM, is sometimes not visible, but very much evident in the assumptions

Wiseman, D., Lunney Borden, L., Beatty, R., Jao, L., \& Carter, E. (2020). Whole-some artifacts: (STEM) Teaching and learning emerging from and contributing to community. Canadian Journal of Science, Mathematics, and Technology Education, 20(2), 264-280. https://doi.org/10.1007/s42330-020-00079-6 
underlying the work. In the following examples, we explore how STEM emerged from the communities where the projects occurred.

Show Me Your Math (Author 2 and Author 5)

In planning for inquiry topics, we identified community-based ideas and practices that have the potential to generate rich mathematical ideas. From birch bark biting to paddle making, from maple syrup making to creating hand drums, we work with teachers to help them think about and plan for mathematical learning opportunities that could potentially arise. Yet, in spite of this planning for mathematics, and teachers seeing evident mathematics, students do not always see it. For example, in the paddle making unit with Grade 8 students where students made their own canoe paddles involved measuring, working with fractions, concepts of symmetry and proportional reasoning. Still many students argued it was "not mathematics" because "It was fun!" Recognizing this insistence that paddle making is not about mathematics, their teacher made explicit connections to the task when teaching their fractions unit. The resistance to naming mathematics was also apparent in some of our early work relating to SMYM; students focused less on the mathematics they used and more on the cultural learning. We posited "this shift to privileging the community knowledge to eclipse mathematics may be completely appropriate in this instance because the typical classroom experience is just the opposite," (Wagner \& Lunney Borden 2011 p. 387).

By comparison, students in CMTOLC, that they refer to as math club, seemed to see everything as mathematics. For example, in comments from the annual program review, students shared the following:

- I learned that mathematics is everywhere. (Student A, April 2017)

Wiseman, D., Lunney Borden, L., Beatty, R., Jao, L., \& Carter, E. (2020). Whole-some artifacts: (STEM) Teaching and learning emerging from and contributing to community. Canadian Journal of Science, Mathematics, and Technology Education, 20(2), 264-280. https://doi.org/10.1007/s42330-020-00079-6 
- I liked that it pointed out the mathematics in everyday activities. I learned that mathematics is in almost every little thing you do. Whenever I do something musical there's a pattern. (Student B, April 2018)

These comments show how students in CMTOLC begin to see everything as being connected to mathematics but they still distinguish this type of mathematics learning from what they are doing in school. For example, students have said:

- I learned that mathematics can be something fun and doesn't have to be some boring class in school and it's very hands on. Mathematics is literally all around us and in our everyday life (Student D, April 2017)

- I like that we learn different things and we don't do any of the things we do in mathematics club at our school. (Student E, April 2018)

We wonder about this disconnect between the mathematics students do when working on the CMTOLC modules and the mathematics they are doing in school. This disconnect seems to echo the ideas of the students in the inquiry projects who saw the application of mathematics in meaningful project work as being somehow not mathematics because it was so far removed from what they typically do in school.

First Nations and Métis Mathematics Voices Project (Author 3)

Mathematics is inherent in all of the cultural activities we explored. Below is an example from the project done in partnership with the Algonquins of Pikwakanagan First Nation and teachers from Eganville and District Public School. Christina, an artist from Pikwakanagan, begins her work in the classroom by sharing the history and importance of beadwork in

Wiseman, D., Lunney Borden, L., Beatty, R., Jao, L., \& Carter, E. (2020). Whole-some artifacts: (STEM) Teaching and learning emerging from and contributing to community. Canadian Journal of Science, Mathematics, and Technology Education, 20(2), 264-280. https://doi.org/10.1007/s42330-020-00079-6 
Anishinaabe culture. Based on Christina's process of design, we created a template of 20 columns and 20 rows (Figure 2).

Fig. 2 The 20-column template provided to students

With Grade 6 students we explored the connection between design and proportional reasoning. Their task was to create a design that would perfectly fit their wrist. The students used a size 10 bead, and ascertained that there are 5 beads in $1 \mathrm{~cm}$. Students multiplied the length of their wrist by 5 to determine the total number of columns required. They then calculated the number of 20column templates needed by dividing the total number of columns by 20 , which allowed students to know how many full templates (each of which represented a unit of repeat,) they would need and how many extra columns they would have. For example, $15 \mathrm{~cm}$ of beadwork requires 75 columns, or three full templates plus 15 more columns (3/4 of a template). Christina showed them one of her designs (Figure 3) and explained that, although she had begun with a simple repeating pattern, in order to make the pattern fit the length she needed she had to augment it. I wanted this bracelet to be a certain length and if I went with another diamond it would be too long. So, I added three layers of border. Really, if you look at the pattern, it's the repeating diamonds. You need to think about how you're going to have a pattern core within the 20 by 20 , how you can repeat the core, and what are you going to do to make sure your design is the right length? (Co-teaching video transcript, April 10, 2017).

Fig. 3 Christina's design showing the repeating pattern and 3 layers of border.

Wiseman, D., Lunney Borden, L., Beatty, R., Jao, L., \& Carter, E. (2020). Whole-some artifacts: (STEM) Teaching and learning emerging from and contributing to community. Canadian Journal of Science, Mathematics, and Technology Education, 20(2), 264-280. https://doi.org/10.1007/s42330-020-00079-6 
Some students used their extra columns as borders on either end of their designs. If they had an odd number of extra columns, they rounded up to the nearest even number and divided by 2 (Figure 4). The resulting patterns were created to specific measurements that determined the space of the design and any additional pieces needed to ensure the bracelets were the correct length.

Fig. 4 Examples of student designs and resulting beadwork.

\section{The READress Project (Author 1 \& Author 4)}

Given the focus on student-directed inquiry, it was always our intention that most elements in the project would emerge from the classroom community. We had also imagined that the choice of topic for any group/collaborative project(s) would come from the students. What we had not imagined was that the choice would be very personal to some of the students, allowing them to bridge their home and school communities, and that a sense of belonging in community would deepen because of a collective choice. That is, one of the students, Mabel, had personal experience of MMIWG, and another, Mia, was from the same home community and knew of her friend's experience. Mia suggested the topic to their group of four when the class was working to develop ideas for presentation to each other. After the presentations, when the results of class voting (each student had one vote) were announced, the teacher noticed Mabel and Mia smiled and fist pumped upon learning their group's topic was chosen. Later, when asked about her reaction to the class choice, Mabel said, "I was kind of surprised because I didn't really

Wiseman, D., Lunney Borden, L., Beatty, R., Jao, L., \& Carter, E. (2020). Whole-some artifacts: (STEM) Teaching and learning emerging from and contributing to community. Canadian Journal of Science, Mathematics, and Technology Education, 20(2), 264-280. https://doi.org/10.1007/s42330-020-00079-6 
think anyone was going to pick it. So it was a really nice surprise that actually people wanted to do it" (interview, June 5, 2018). Exit tickets on the day of the initial vote indicated that other students recognized these personal connections as important to the community in the class, but also to a broader community. For example, Ivy wrote

- It's [s]ad that they [Mabel and Mia] were involved in this with their loved ones. They weren't just watching it from afar. [...] People think Canada (while it's an amazing place) is perfect but it isn't. Indigenous people have rights. Since I'm a white/hispanic girl ... I want to learn more. (Ivy, exit ticket, October 24, 2017)

In moving from choosing the topic of MMIWG, to discussions of raising awareness, once again, we tossed the question back to students: What does it means to raise awareness? What might you do to raise awareness? They came up with 11 possibilities and consensus around what to do was somewhat challenging. So, we moved on to a weighted vote, where students had 9 points each to allot over three options. The points were broken down into 5, 3, and 1 point votes (see Figure 5). They could use the three votes on three different options they liked, in various combinations for two options they liked, or place all votes on one option. To ensure they understood the weighted system, we had a group discussion of how the various combinations of votes might play out. In retrospect, we could have-but did not-had conversations about firstpast-the-post versus ranked ballot systems, around the two voting methods employed. This may have been interesting as an example of other conversations of national importance (see Noik, 2016) and how mathematics is active in these instances. When the results were tallied, students had chosen the paper dresses, followed by dreamcatchers, and ornaments as a means of raising awareness.

Wiseman, D., Lunney Borden, L., Beatty, R., Jao, L., \& Carter, E. (2020). Whole-some artifacts: (STEM) Teaching and learning emerging from and contributing to community. Canadian Journal of Science, Mathematics, and Technology Education, 20(2), 264-280. https://doi.org/10.1007/s42330-020-00079-6 
Fig. 5 Votes for the dresses. Students had 9 points each to distribute over options. The 9 points were broken into 5 (circles), 3 (triangles), and 1 (Xs) point chunks.

So, the M in STEM emerged from the community in which we were engaged, when the students were asked to think specifically about mathematics. In examining student work-which occurred publicly on tables covered with white board paper (Figure 6)-we can see how community was important to what emerged, because students were building off other students' ideas. We also see students noticing elements of symmetry in mapping, measuring, and explaining (Bishop 1988), in exit tickets on days when they worked on planning and patterning their dresses. In particular, students highlighted how taking measurements for designing the dresses was easy, but that mapping measurements on to a developing pattern on paper was more challenging, and a skill that required more support from the adults in the class. At the same time, we are not certain the mathematics that went into making the paper dresses was as evident to the students as it was to us as instructors (Wiseman, Kim, Jao, \& Boutros, 2019). However, given the learning and unlearning students did in relation to MMIWG as the project progressed, we wonder if this lack of explicit connect for students is important or not.

Fig. 6 Student thinking about where mathematics might apply to their chosen options.

\section{STEM contributing to communities}

Wiseman, D., Lunney Borden, L., Beatty, R., Jao, L., \& Carter, E. (2020). Whole-some artifacts: (STEM) Teaching and learning emerging from and contributing to community. Canadian Journal of Science, Mathematics, and Technology Education, 20(2), 264-280. https://doi.org/10.1007/s42330-020-00079-6 
Both reciprocity (Kirkness \& Barnhardt 1991) and ethical relationality (Donald 2009, 2012) underline the importance of two-way relationships between people, peoples, and communities. Reciprocity speaks to the "impact of motives and intentions on person and community" and "the sacredness and the responsibility of maintaining personal and community integrity" (Weber-Pillwax 1999 pp. 31-32), or as Donald (2018) says, how we "face each other as human beings". Both approaches therefore suggest a cyclical giving and giving back within and between communities in ways that care for relationship, and thus go beyond one-off contributions based on instrumental approaches to exchange (Kirkness \& Barnhardt 1999). In teaching and learning, such caring is a pedagogical choice, which may be visible but is more often recognized through the experiences of the beings involved. The examples that follow illustrate how the projects aimed to contribute to community/ies in this manner.

Show Me Your Math (Author 2 \& Author 5)

SMYM and CMTOLC have been embraced by the communities, and the ideas that began as innovations in the early days of SMYM, have become commonplace in Mi'kmaw Kina'matnewey (MK) schools. While we do not have an official SMYM program anymore, teachers from both MK and provincial public schools regularly call upon us for support with culturally and community based inquiry projects. For example, the first CMTOLC module was inspired by a conversation between a teacher from one of our SMYM participating schools and Lisa in a graduate course examining equity and culturally relevant pedagogy in mathematics. Working on social justice issues in mathematics, the two turned their attention to the matter of on-going poor water quality in the community, an issue recognized as a crisis in Canadian First Nations communities (Human Rights Watch 2016).

Wiseman, D., Lunney Borden, L., Beatty, R., Jao, L., \& Carter, E. (2020). Whole-some artifacts: (STEM) Teaching and learning emerging from and contributing to community. Canadian Journal of Science, Mathematics, and Technology Education, 20(2), 264-280. https://doi.org/10.1007/s42330-020-00079-6 
In the water security module, students explored data from the Halifax Regional Municipality (HRM) that reported average water usage, in cubic metres, based on the number of people in a household over a period of three months. To make sense of the data, students built a cubic metre model to visualize $1 \mathrm{~m}^{3}$ (Figure 7). This enabled students to make predictions about their household water needs for one year and to develop a sense of the space that would be occupied by that water. By combining their annual totals with those of the other students at CMTOLC, they extended the data to community requirements. The introduction of base-ten materials in relation to the cubic metre allowed students to explore conversion in that 1000 of the large cubes $(10 \mathrm{~cm}$ by $10 \mathrm{~cm}$ by $10 \mathrm{~cm})$ would fit in the cubic metre. Additionally, the use of the small $1 \mathrm{~cm}^{3}$ as one millionth of the cubic metre allowed for the investigation of water quality and contaminants, measured in parts per million.

Fig. 7 Student building models of cubic metres

The teacher, who also helped with CMTOLC, was pleased to have her students (Grades 1-7) interview Elders and community members about their knowledge of the boil water orders, and then collecting, displaying, and sharing their interview data and findings with the community. The students were quite surprised to learn that despite the boil water order, many community members were unaware or continuing to use the unsafe water. The students also interviewed the person responsible for the water system in the community to learn what was wrong and how it would be fixed. Students created a video in the style of a news broadcast to share their learning at the local math fair as well as with the community.

Wiseman, D., Lunney Borden, L., Beatty, R., Jao, L., \& Carter, E. (2020). Whole-some artifacts: (STEM) Teaching and learning emerging from and contributing to community. Canadian Journal of Science, Mathematics, and Technology Education, 20(2), 264-280. https://doi.org/10.1007/s42330-020-00079-6 
This is just one example of how the CMTOLC modules emerge from community and subsequently impact communities through the collaborative nature of this program. We strive to help youth see that such application of mathematical thinking can be a powerful tool to address community issues.

\section{First Nations and Métis Mathematics Voices Project (Author 3)}

The Indigenous members of the research teams shared how they believe this project has contributed to the communities during a focus group interview held on December 10, 2018. They spoke about the importance of taking time to build relationships within the research teams, local community leaders, and participating educators. This aligns with Simpson's (2017) outline of Nishnaabeg research ethics, which emphasize "consent, reciprocity, respect, renewal and relationship" (p. 57) and builds from Kirkness and Barnhardt's (1991) four Rs. Jody, a research team member from Pikwakanagan, stated,

In the past, people came into the community and did the research and they left. But with this project, we've invested the time and it's been sustainable and we've continued with it year after year, so I think that helps to build the trust too.

The relationships that develop during the research project then extend to other aspects of school culture. As more community members come into the school to take part in the project, Jody explained how they became more invested in the work.

I remember that meeting that we had with Pikwakanagan and we showed some of the video and you could just see the love in their eyes. They were just so happy that we were doing this work and that it was having an impact. And I remember one grandma talking

Wiseman, D., Lunney Borden, L., Beatty, R., Jao, L., \& Carter, E. (2020). Whole-some artifacts: (STEM) Teaching and learning emerging from and contributing to community. Canadian Journal of Science, Mathematics, and Technology Education, 20(2), 264-280. https://doi.org/10.1007/s42330-020-00079-6 
about how she could see her granddaughter's spirit coming alive when she was engaging in this work.

The experience of being part of a collaborative research team has had a profound effect on the community partners who provide the artistic guidance for the projects. All of the artists are accomplished in diverse forms of artistry, but although highly skilled, most were initially apprehensive about participating in a project exploring mathematics. Through the project community members have discovered that they are, in fact, deeply mathematical in their thinking, and that they can articulate the mathematics that they have always utilized in their artwork. Colinda shared the experience of a Métis beader who had worked on several projects with the Upper Grand District School Board.

I love when we talk about the community members owning the projects. I look at one community partner in particular who was very apprehensive and nervous about doing the work from the mathematics perspective. She was comfortable with teaching beading, but then to see her understand and see herself as a mathematics learner too! And then not just leading the beading instruction in future projects, but also leading the mathematics talk with the students. Now, working on different projects with her, she's different. Her selfconfidence has blossomed. And I think that's true reconciliation.

\section{The READress Project (Author $1 \& 4$ )}

Because this project arose from school and teacher-identified priorities, there was some sense at the beginning of the work that it would give back to the school community by addressing issues of local importance and to members of the project community based on collective learning. We did not realize how quickly such contributions would begin to play out,

Wiseman, D., Lunney Borden, L., Beatty, R., Jao, L., \& Carter, E. (2020). Whole-some artifacts: (STEM) Teaching and learning emerging from and contributing to community. Canadian Journal of Science, Mathematics, and Technology Education, 20(2), 264-280. https://doi.org/10.1007/s42330-020-00079-6 
or how permeable the boundaries of our small classroom community were. For example, in the first two sessions of the project, it became apparent how much support students required to formulate questions. When their teacher, Raina, shared her observations of student struggles with her colleagues, they subsequently requested copies of the resources for the questioning activities in order to inform practices across the school beyond the science and technology course.

More generally, over the course of the academic year, the focus on student-directed STEAM worked to develop a strong sense of community among the students. One of Raina's hopes within the project was that they developed a collective sense of accomplishment where they could say "We did this" particularly since "Grade 7 kids don't really have any control. They're at the bottom of the, whatever, the ladder, ... they don't get to choose very much" (Interview, June 28, 2018). This collective sense of self-efficacy and community developed as students collaborated and became supportive of each other's work. Furthermore, it was evident in actions throughout the project, but also in comments they made both when they completed their dresses and after the vernissage:

- I could really see how much work everyone put in and I could see the difference between the sketch and end result. (Cait, exit ticket, June 5, 2018)

- I feel very proud of myself and all my classmates because we are raising awareness for a horrible cause. (Aaliyah, exit ticket, October 18, 2018)

- My favourite part was Naia and Gabby's speech because it mentioned our entire year long process. (Mabel, exit ticket, October 18, 2018)

Students could and did talk about mathematics as one of many things they did while engaged in the project. In their speech at the vernissage, Naia and Gabby noted the designing, measuring,

Wiseman, D., Lunney Borden, L., Beatty, R., Jao, L., \& Carter, E. (2020). Whole-some artifacts: (STEM) Teaching and learning emerging from and contributing to community. Canadian Journal of Science, Mathematics, and Technology Education, 20(2), 264-280. https://doi.org/10.1007/s42330-020-00079-6 
and explaining they had done in the project. But, these considerations about what they did in terms of mathematics and other STEAM areas were secondary to the manner in which connections within and across communities impacted their learning well beyond STEAM. As they said:

Mrs. Hibou came in to class in order to teach us more about our cause. She taught us what [MMIWG] stands for and how these women are real people and that they meant and still mean something to their loved ones left behind. She told us what it was like to lose someone and not get help to find them. It was then that we realized that this situation wasn't just one little problem. It's a huge situation that needs to be recognized by the authorities and everyday people. Mrs. Hibou lost her sister, and it took years for the police to even glance at her case. She kindly let us ask her questions and share ideas about our individual dresses with her. She also helped us to know if the things we were thinking of putting on our dresses were appropriate and respectful towards the Indigenous community and the many victims of this tragedy. (speech, October 18, 2018).

Giving another perspective, the class teacher, Raina, reflected that the project had been perhaps less explicitly cross-curricular than she had imagined at the beginning of the academic year. Yet, in her speech at the vernissage, she spoke of the value of the project and its approach:

I know this type of learning is risky but the benefits far outweigh the risks. Benefits like fostering curiosity, which happens to be one of our school's guiding principles, giving students agency in their learning, learning to fail forward, and valuing process over product. (speech, October 18, 2018)

Wiseman, D., Lunney Borden, L., Beatty, R., Jao, L., \& Carter, E. (2020). Whole-some artifacts: (STEM) Teaching and learning emerging from and contributing to community. Canadian Journal of Science, Mathematics, and Technology Education, 20(2), 264-280. https://doi.org/10.1007/s42330-020-00079-6 
We continue to work in community with the school around teaching and learning, nominally in relation to STEAM because this is where our expertise lies and where we can make contributions. But we feel that Raina, perhaps hit the nail on the head in her concluding thoughts about the project, when she described how it can be risky to break down disciplinary boundaries in systems where such things are valued and used to measure student success-but perhaps what occurs in doing so is worth it anyway.

\section{The strands and the braid}

In considering the strands as a braided wholesome artifact we see commonalities between the projects that provide insight into what it means to engage in this work in ethically relational ways. Each project involves elements of co-planning, co-teaching, and the co-creation of meaning taken up in reflective cyclical processes of teaching and learning that emerge from ideas identified and important to the specific communities involved and that give back to those communities in ways beyond the scope of STEM. In each project, local participants-students, teachers, artists, Elders, etc.-identified deep connections with the processes and learnings involved. These are all positive outcomes, and we underline their importance for the broader teaching and education research communities in terms of how they create space instead of taking it up.

Within the projects we also see that when students engage with mathematics in context it becomes something doable, but often invisible. As educators we can empirically note mathematical skills and understandings being meaningfully developed and applied in each project, but we note that when asked about or pointed out to students how what arises might be mathematics, the meaningfulness students identify in the learning is about context and

Wiseman, D., Lunney Borden, L., Beatty, R., Jao, L., \& Carter, E. (2020). Whole-some artifacts: (STEM) Teaching and learning emerging from and contributing to community. Canadian Journal of Science, Mathematics, and Technology Education, 20(2), 264-280. https://doi.org/10.1007/s42330-020-00079-6 
community (e.g. Wiseman, Kim, Jao, \& Boutros 2020). As we think about this phenomena, it allows us to recognize the colonizing possibilities of mathematics as those systemic structures that erase context and knowledge systems, that impose on and occupy places where people are already living with mathematics, and that attempt to replace complex conceptions of community with general and abstract ideas that belong nowhere and are therefore lifeless. It is one of the reasons that in the projects described here, we seek life by engaging with communities in ways that they identify as addressing the fall out of Western, colonial structures including underrepresentation of specific communities in STEM and mathematics as a gatekeeper in K-12 and tertiary education.

As a closing thought, we underline that Tuck and McKenzie (2015) identify classification and the separation of life into manageable, disciplined areas as one of the primary activities of colonialism that is clearly reproduced in education. And so we wonder if a focus on mathematics is recolonizing, or reifying of the colonial project as a whole. It is hard to be certain with respect to the projects described here, which emerge from and contribute back to community, and where the mathematics often occurs within more whole-some relationships. This approach, we hope, challenges colonial processes. Yet, we know the need for visible mathematics comes from its privileging in provincial and territorial curricula that is informed by Western ways of knowing, being, and doing, and neoliberal (and colonial) assumptions (Sattler 2012; Wiseman, 2016). So, perhaps the tensions we struggle with are not so much about mathematics as they are about curricula and the assumptions that underlie it. Perhaps there is also a need to investigate how the curriculum is being transformed to address the mandates we outlined at the beginning of this paper. Are provincial authorities, responsible for writing curriculum, trying to tinker with

Wiseman, D., Lunney Borden, L., Beatty, R., Jao, L., \& Carter, E. (2020). Whole-some artifacts: (STEM) Teaching and learning emerging from and contributing to community. Canadian Journal of Science, Mathematics, and Technology Education, 20(2), 264-280. https://doi.org/10.1007/s42330-020-00079-6 
existing curriculum to map Indigenous perspectives on to it, or are they attempting to truly transform curriculum to address Indigenous ways of knowing, being and doing?

In the midst of current struggles around genocide, pipelines, natural gas storage, and Indigenous sovereignty, Sanderson (2019) points out the duty to consult involves not only instrumental consultation with Indigenous communities, but accommodation and adaptation based on their input, where the state cedes power and control to Indigenous communities; something perhaps a bit more like collaborations based in ethical relationality (Donald 2009, 2012) which may lead to the emergence of new types of community. We note these struggles around genocide, pipelines, natural gas storage, and Indigenous sovereignty are very much the kind of real world issues students engage in with STEM. And so perhaps curriculum requires a similar shift, a similar duty to consult where the duty is based on facing each other as human beings (Donald 2018), living together, and building new kinds of community. Perhaps then curricula might become not about disciplining but living together with young people in teaching and learning. But we cannot be sure, so we continue to sit with the tensions, return to work with community, and learn more.

All procedures performed in studies involving human participants were in accordance with the ethical standards of the Tri-Council Policy Statement: Ethical Conduct for Research Involving Humans (Canadian Institutes of Health Research, Natural Science and Engineering Research Council of Canada, \& Social Science and Humanities Research Council Canada 2010) and with the 1964 Helsinki declaration and its later amendments or comparable ethical standards.

Wiseman, D., Lunney Borden, L., Beatty, R., Jao, L., \& Carter, E. (2020). Whole-some artifacts: (STEM) Teaching and learning emerging from and contributing to community. Canadian Journal of Science, Mathematics, and Technology Education, 20(2), 264-280. https://doi.org/10.1007/s42330-020-00079-6 
Wiseman, D., Lunney Borden, L., Beatty, R., Jao, L., \& Carter, E. (2020). Whole-some artifacts: (STEM) Teaching and learning emerging from and contributing to community. Canadian Journal of Science, Mathematics, and Technology Education, 20(2), 264-280. https://doi.org/10.1007/s42330-020-00079-6 


\section{References}

Alberta Education. (2018). Teacher quality standard. Retrieved from https://education.alberta.ca/media/3739620/standardsdoc-tqs-_fa-web-2018-01-17.pdf

Aoki, T. T. (2005). Legitimating lived curriculum: Toward a curricular landscape of multiplicity. In W. F. Pinar \& R. L. Irwin (Eds.), Curriculum in a new key: The collected works of Ted. T. Aoki (pp. 199-215). Mahwah, NJ: Lawrence Erlbaum Associates, Publishers. Association of Canadian Deans of Education. (2010). Accord on Indigenous education.

Retrieved from http://www.cssescee.ca/docs/acde/acde_indigenouseducationaccord_en.pdf

Bielaczyc, K., Kapur, M., \& Collins, A. (2013). Cultivating a community of learners in K-12 classrooms. In C. E. Hmelo-Silver, A. M. O’Donnell, C. Chan, \& C. A. Chinn (Eds.), International Handbook of Collaborative Learning(pp. 233-249). Taylor \& Francis.

Bishop, A. (1988) mathematical enculturation. Dordrecht: Kluwer.

Black, J. (2014) The REDress project. Retrieved from http://www.redressproject.org

Bryk, A. S., \& Driscoll, M. E. (1988). The high school as community: Contextual influences and consequences for students and teachers. Madison, WI: National Center on Effective Secondary Schools.

Bybee, R.W. (2010a). Advancing STEM education: A 2020 vision. Technology and Engineering Teacher, 70(1), 30-35.

Bybee, R.W. (2010b).What is STEM education? Science, 329, 996. doi:10.1126/science.1194998

Cajete, G. A. (1994). Look to the mountain: An ecology of Indigenous education. Skyland, NC: Kivaki Press.

Wiseman, D., Lunney Borden, L., Beatty, R., Jao, L., \& Carter, E. (2020). Whole-some artifacts: (STEM) Teaching and learning emerging from and contributing to community. Canadian Journal of Science, Mathematics, and Technology Education, 20(2), 264-280. https://doi.org/10.1007/s42330-020-00079-6 
Canadian Institutes of Health Research, Natural Science and Engineering Research Council of Canada, \& Social Science and Humanities Research Council Canada. (2010). Tri-Council Policy Statement: Ethical Conduct for Research Involving Humans. Retrieved from http://www.ethics.gc.ca/pdf/eng/tcps2/TCPS_2_FINAL_Web.pdf

Chambers, C., Hasebe-Ludt, E., Donald, D. T., Hurren, W., Leggo, C., \& Oberg, A. (2008). Métissage: A research praxis. In J. G. Knowles \& A. L. Cole (Eds.), Handbook of the Arts in Qualitative Research: Perspectives, methodologies, examples, and issues (pp. 142-155). Thousand Oaks, CA: Sage Publications, Inc.

Cnaan, R. A., Milofsky, C., \& Hunter, A. (2008). Creating a frame for understanding local organizations. In R. A. Cnaan \& C. Milofsky (Eds.),Handbook of community movements and local organizations, (pp. 1-19). New York, NY: Springer.

Davis, B., Sumara, D., \& Luce-Kapler, R. (2015). Cultures of education and practices of teaching(3rd ed.). New York, NY: Routledge.

Donald, D. T. (2018, November). Unlearning colonialism: Holism and ethical relationality as cultural forms that can heal us. Gallop-Dickson Indigenous Education Lecture. School of Education, Bishop's University. Sherbrooke, QC.

Donald, D. T. (2012). Indigenous metissage: A decolonizing research sensibility. International Journal of Qualitative Studies in Education, 25(5), 533-555. DOI: $10.1080 / 09518398.2011 .554449$

Donald, D. T. (2009). The Pedagogy of the Fort: Curriculum, Aboriginal-Canadian Relations, and Indigenous Metissage. Unpublished Doctoral Dissertation. Department of Secondary Education, University of Alberta. Edmonton, AB.

Wiseman, D., Lunney Borden, L., Beatty, R., Jao, L., \& Carter, E. (2020). Whole-some artifacts: (STEM) Teaching and learning emerging from and contributing to community. Canadian Journal of Science, Mathematics, and Technology Education, 20(2), 264-280. https://doi.org/10.1007/s42330-020-00079-6 
Donald, D. T., Glanfield, F. A., \& Sterenberg, G. (2012). Living ethically within conflicts of colonial authority and relationality. Journal of the Canadian Association for Curriculum Studies, 10(1), 53-77. Retrieved from http://jcacs.journals.yorku.ca/index.php/jcacs/article/view/34405.

Franz, B. A., Skinner, D., \& Murphy, J. W. (2018). Defining "community" in community health evaluation: Perspectives from a sample of nonprofit Appalachian hospitals. American Journal of Evaluation, 39(2), 237-256. DOI: 10.1177/1098214017722857

Furman, G. (2012). School as community: From promise to practice. New York, NY: SUNY Press.

Garcia, G. E., \& Ingram Willis, A. (2016). Frameworks for promoting multicultural literacies: Moving toward educational justice. In P. Ruggiano Schmidt \& A.M. Lazar (Eds.), Reconceptualizing literacy in the new age of multiculturalism and pluralism, $2^{\text {nd }}$ ed. (pp. 3-38). Charlotte, NC: Information Age Publishing.

Government of Canada. (2018a). The Government of Canada and STEM. Retrieved from https://www.ic.gc.ca/eic/site/013.nsf/eng/00014.html

Government of Canada. (2018b). What new ways of learning, particularly in higher education, will Canadians need to thrive in an evolving society and labour market?Retrieved from https://www.ic.gc.ca/eic/site/013.nsf/eng/00014.html

Grossman, P., Wineburg, S., \& Woolworth, S. (2001). Toward a theory of teacher community. Teachers College Record, 103(6), 942-1012.

Gutstein, E. (2006). Reading and writing the world with mathematics: Toward a pedagogy for social justice. Taylor \& Francis.

Wiseman, D., Lunney Borden, L., Beatty, R., Jao, L., \& Carter, E. (2020). Whole-some artifacts: (STEM) Teaching and learning emerging from and contributing to community. Canadian Journal of Science, Mathematics, and Technology Education, 20(2), 264-280. https://doi.org/10.1007/s42330-020-00079-6 
Hadar, L., \& Brody, D. (2010). From isolation to symphonic harmony: Building a professional development community among teacher educators. Teaching and Teacher Education, 26(8), 1641-1651.

Hillary, G. A. (1955). Definitions of community: Areas of agreement. Rural Sociology, 20, 111123.

Human Rights Watch. (2016). Canada's obligation to end the First Nations water crisis.

Retrieved from https://www.hrw.org/report/2016/06/07/make-it-safe/canadas-obligationend-first-nations-water-crisis\#

Ihde, D. (1996). Whole earth measurements: How many phenomenologists does it take to detect a 'greenhouse effect'. Techné: Research in Technology and Philosophy, 2(2). Retrieved from http://scholar.lib.vt.edu/ejournals/SPT/v2n2/.

Kirkness, V. J., \& Barnhardt, R. (1991). First Nations and higher education: The four Rs-respect, relevance, reciprocity, responsibility. Journal of American Indian Education, 30(3), 1-15.

Lunney Borden, L., Wagner, D., and Johnson, N. (2019). Show me your math: Mi'kmaw community members explore mathematics. In Nicol, C.; Dawson, S.; Archibald, J. \& Glanfield, F. (Eds) Living Culturally Responsive Mathematics Curriculum and Pedagogy: Making a Difference with/in Indigenous Communities. Rotterdam, NL: Sense Publishers.

Lunney Borden, L., \& Wiseman, D. (2016). Considerations from places where Indigenous and Western ways of knowing, being, and doing circulate together: STEM as artifact of teaching and learning. Canadian Journal of Science, mathematics and Technology Education, 16(2), 140-152. DOI: 10.1080/14926156.2016.1166292

Wiseman, D., Lunney Borden, L., Beatty, R., Jao, L., \& Carter, E. (2020). Whole-some artifacts: (STEM) Teaching and learning emerging from and contributing to community. Canadian Journal of Science, Mathematics, and Technology Education, 20(2), 264-280. https://doi.org/10.1007/s42330-020-00079-6 
Meyer, M. A. (2013, December 8). Mana moana! Pasifika rises! Idle No More webinar. Retrieved from http://www.youtube.com/watch?v=DQi62rEYo-8

Noik, S. (2016, May 11). Electoral reform: A primer on the main alternatives to how we vote. CBC News. Retrieved from https://www.cbc.ca/news/politics/electoral-reform-types1.3577721

Ontario Ministry of Education. (2007). Ontario First Nation, Métis and Inuit education framework: Delivering quality education of Aboriginal students in Ontario's provincially funded schools. Toronto, ON: Government of Ontario. Retrieved from http://www.edu.gov.on.ca/eng/aboriginal/fnmiFramework.pdf

Sanderson, D. (2019, March 11). How to treat First Nations as equals?: Abandon your consultations. Policy Options Politiques. Retrieved from http://policyoptions.irpp.org/magazines/march-2019/treat-first-nations-equals-abandonconsultations/

Sattler, P. (2012). Education governance reform in Ontario: Neoliberalism in context. Canadian Journal of Educational Administration and Policy, 128, 12-28.

Sergiovanni, T. J. (1994). Building community in schools. San Francisco, CA: Jossey-Bass.

Simpson, L. B. (2017). As we have always done: Indigenous freedom through radical resistance. Minneapolis: University of Minnesota Press.

Smith, L. T. (1999). Decolonizing methodologies: Research and Indigenous peoples. London: Zed Books.

Todd, Z. S. (2019, March 9). Time and place [Blog post]. Retrieved from https://zoestodd.com/2019/03/09/time-and-place/

Wiseman, D., Lunney Borden, L., Beatty, R., Jao, L., \& Carter, E. (2020). Whole-some artifacts: (STEM) Teaching and learning emerging from and contributing to community. Canadian Journal of Science, Mathematics, and Technology Education, 20(2), 264-280. https://doi.org/10.1007/s42330-020-00079-6 
Truth and Reconciliation Commission of Canada. (2015a). Calls to action. Winnipeg, MB: Author. Retrieved from http://www.trc.ca/websites/trcinstitution/File/2015/Findings/Calls_to_Action_English2.p df

Tuck, E., \& McKenzie, M. (2015). Place in research: Theory, methodology, and methods. New York, NY: Routledge.

Tuck, E., \& Yang, K. W. (2014). R-words: Refusing research. In D. Paris \& M. T. Winn (Eds.), Humanizing research: Decolonizing qualitative inquiry with youth and communities (pp. 223-247). Thousand Oaks, CA: Sage.

Universities Canada (2015, June 29). Principles on Indigenous education. Retrieved from https://www.univcan.ca/media-room/media-releases/universities-canada-principles-onindigenous-education/

Wagner, D. \& Lunney Borden, L. (2012). Aiming for equity in mathematics education research in a marginalized community: A perspective from Canada. In Choppin, J., HerbelEisenmann, B., Pimm, D. \& Wagner, D. (Eds.). Equity in Discourse for Mathematics Education: Theories, Practices and Policies. Springer, New York, NY, pp. 69-87.

Wagner, D. \& Lunney Borden, L. (2011). Qualities of Respectful Positioning and their Connections to Quality Mathematics. In Atweh, B., Graven, M., Secada, W., and Valero, P. (Eds). Mapping Equity and Quality in Mathematics Education. Springer: New York, NY, pp. 379-391.

Wallin, J. J. (2011). What is ?curriculum theorizing: For a people yet to come. Studies inPhilosophy and Education, 30(3), 285-301. DOI 10.1007/s11217-010-9210-y

Wiseman, D., Lunney Borden, L., Beatty, R., Jao, L., \& Carter, E. (2020). Whole-some artifacts: (STEM) Teaching and learning emerging from and contributing to community. Canadian Journal of Science, Mathematics, and Technology Education, 20(2), 264-280. https://doi.org/10.1007/s42330-020-00079-6 
Warren, M. (2005). Communities and schools: A new view of urban education reform. Harvard Educational Review, 75(2), 133-173.

Weber-Pillwax, C. (1999). Indigenous research methodology: Exploratory discussion of an elusive subject. Journal of Educational Thought, 33(1) 31-45.

Wilson, S. (2008). Research is ceremony: Indigenous research methods. Halifax, NS: Fernwood Publishing.

Wiseman, D. (2016). Acts of living with: Being, doing, and coming to understand Indigenous perspectives alongside science curricula. Unpublished doctoral dissertation. Department of Secondary Education, University of Alberta. Retrieved from https://era.library.ualberta.ca/files/ctt44pm87m/Wiseman_Dawn_201603_PhD.pdf

Wiseman, D., Kim, K., Jao, L., \& Boutrous, I. (2020). What is meaningful to students in meaningful student-directed STEAM inquiry? Paper presented at the American Education Research Association Annual Meeting. San Francisco, CA.

Wiseman, D., Onuczko, T., \& Glanfield, F. (2015). Resilience and hope in the garden: Intercropping Aboriginal and Western ways of knowing to inquire into teaching and learning science. In H. Smits \& R. Naqvi (Eds)., Framing peace: Thinking about and enacting curriculum as “radical hope”, (pp. 237-252). New York, NY: Peter Lang Publishing.

Young, T. M., Spigner, C., Farwell, N., \& Stubblefield, M. (2006). Defining “community": Perceptions of East African and Southeast Asian immigrant and refugee youths residing in public housing sites. Journal of Immigrant and Refugee Studies, 4(4), 55-68.

Wiseman, D., Lunney Borden, L., Beatty, R., Jao, L., \& Carter, E. (2020). Whole-some artifacts: (STEM) Teaching and learning emerging from and contributing to community. Canadian Journal of Science, Mathematics, and Technology Education, 20(2), 264-280. https://doi.org/10.1007/s42330-020-00079-6 
Zecihner, K., Payne, K. A., \& Brayko, K. (2014). Democratizing teacher education. Journal of Teacher Education, 16(2), 122-135. DOI: 10.1177/0022487114560908

Zollman, A. (2011). Is STEM misspelled? School Science and Mathematics, 111(5), 197-198.

Zollman, A. (2012). Learning for STEM literacy: STEM literacy for learning. School Science and Mathematics, 112(1), 12-19.

Wiseman, D., Lunney Borden, L., Beatty, R., Jao, L., \& Carter, E. (2020). Whole-some artifacts: (STEM) Teaching and learning emerging from and contributing to community. Canadian Journal of Science, Mathematics, and Technology Education, 20(2), 264-280. https://doi.org/10.1007/s42330-020-00079-6 


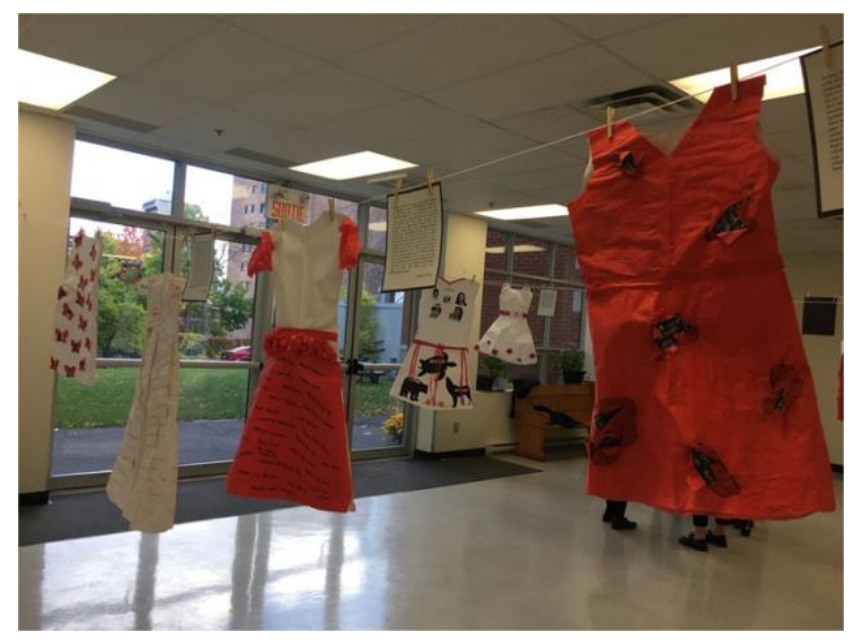

Fig. 1 Student dresses hanging for the project vernissage.

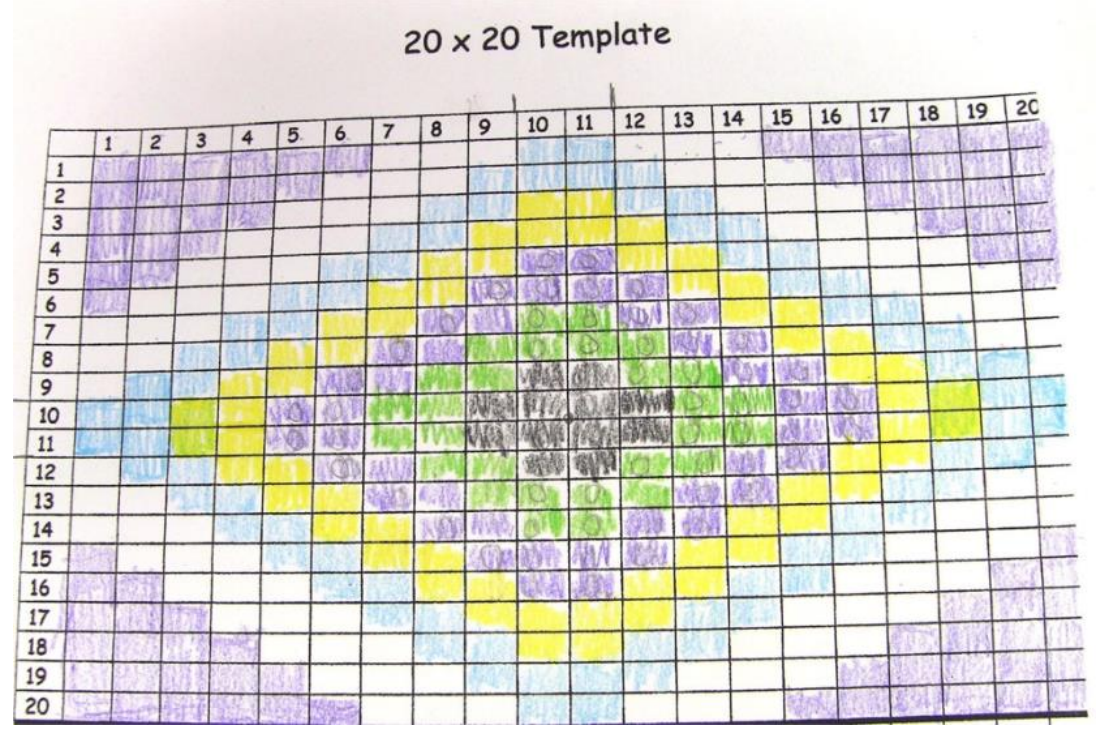

Fig. 2 The 20-column template provided to students

Wiseman, D., Lunney Borden, L., Beatty, R., Jao, L., \& Carter, E. (2020). Whole-some artifacts: (STEM) Teaching and learning emerging from and contributing to community. Canadian Journal of Science, Mathematics, and Technology Education, 20(2), 264-280. https://doi.org/10.1007/s42330-020-00079-6 


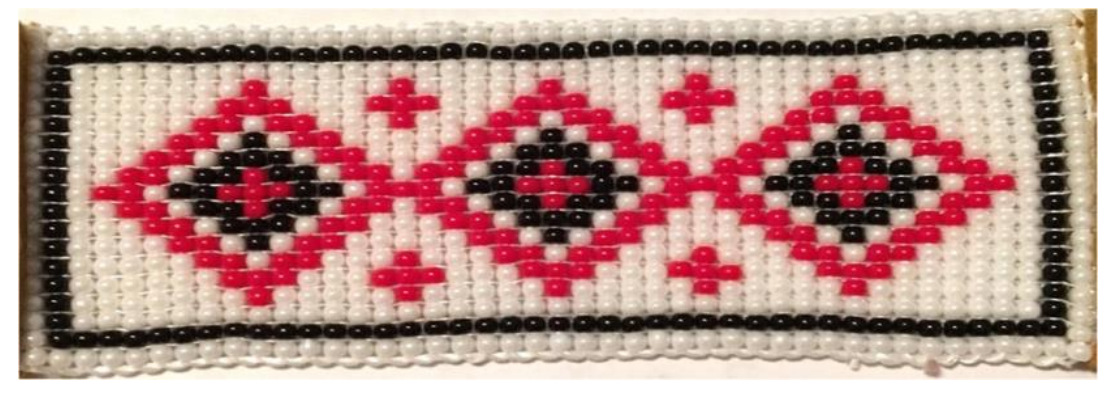

Fig. 3 Christina's design showing the repeating pattern and 3 layers of border.
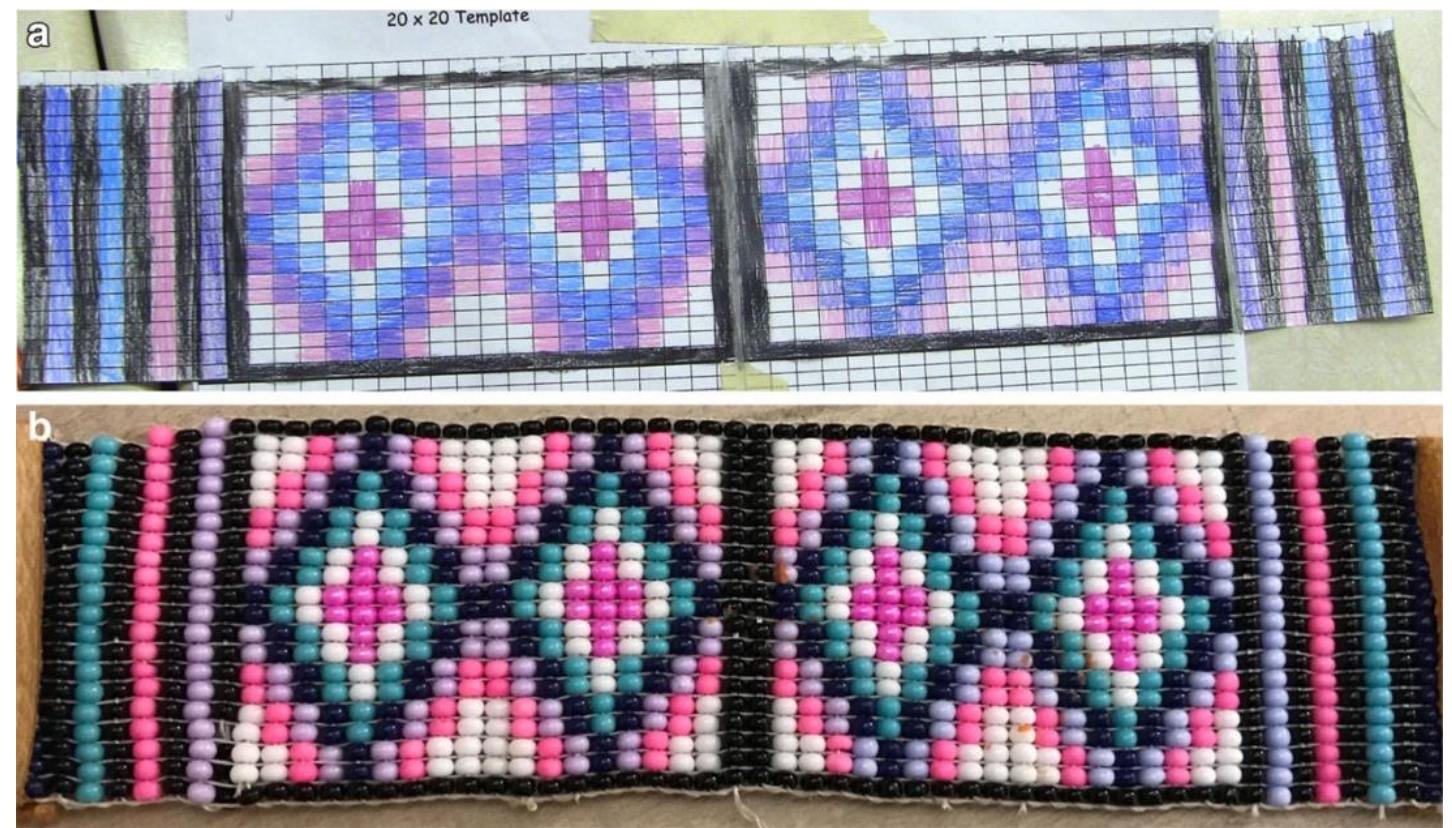

Fig. 4 Examples of student designs and resulting beadwork.

Wiseman, D., Lunney Borden, L., Beatty, R., Jao, L., \& Carter, E. (2020). Whole-some artifacts: (STEM) Teaching and learning emerging from and contributing to community. Canadian Journal of Science, Mathematics, and Technology Education, 20(2), 264-280. https://doi.org/10.1007/s42330-020-00079-6 


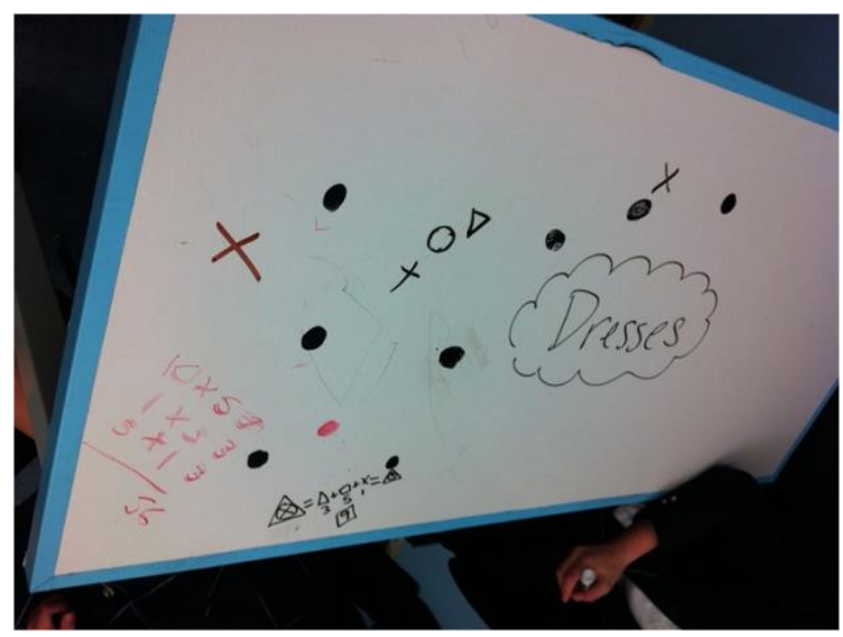

Fig. 5 Votes for the dresses. Students had 9 points each to distribute over options. The 9 points were broken into 5 (circles), 3 (triangles), and 1 (Xs) point chunks.

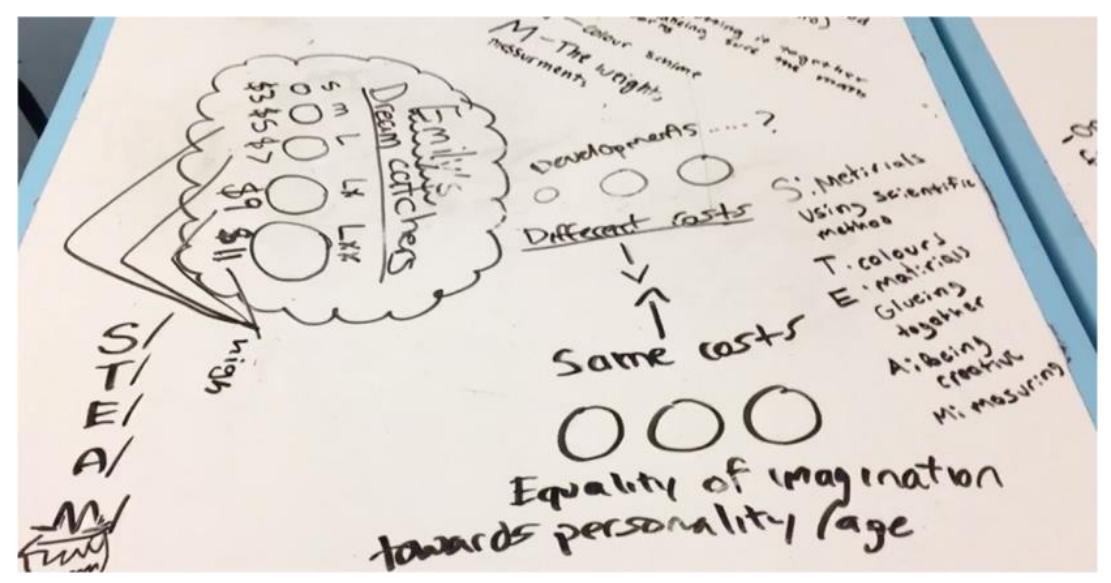

Fig. 6 Student thinking about where mathematics might apply to their chosen options.

Wiseman, D., Lunney Borden, L., Beatty, R., Jao, L., \& Carter, E. (2020). Whole-some artifacts: (STEM) Teaching and learning emerging from and contributing to community. Canadian Journal of Science, Mathematics, and Technology Education, 20(2), 264-280. https://doi.org/10.1007/s42330-020-00079-6 


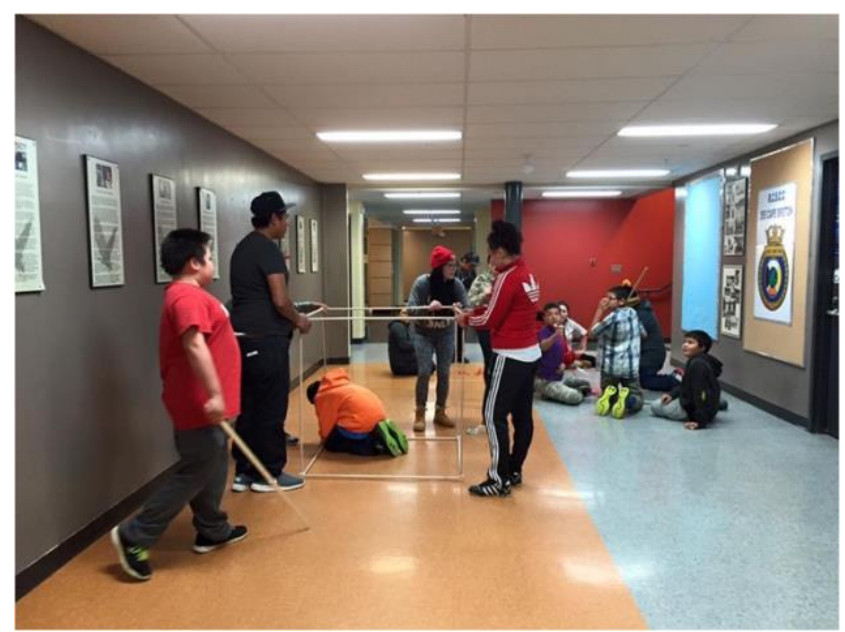

Fig. 7 Student building models of cubic metres

Wiseman, D., Lunney Borden, L., Beatty, R., Jao, L., \& Carter, E. (2020). Whole-some artifacts: (STEM) Teaching and learning emerging from and contributing to community. Canadian Journal of Science, Mathematics, and Technology Education, 20(2), 264-280. https://doi.org/10.1007/s42330-020-00079-6 